\title{
Pendidikan dan Pelatihan Memoderasi Pengaruh Kemampuan Teknik Personal dan IT Sophistication pada Kinerja SIA
}

\author{
I Gusti Agung Pradnya Utami ${ }^{1}$ \\ Fakultas Ekonomi dan Bisnis \\ Universitas Udayana, Indonesia
}

\author{
Ni Luh Sari Widhiyani ${ }^{2}$ \\ Fakultas Ekonomi dan Bisnis \\ Universitas Udayana, Indonesia
}

Surel : utamipradnya58@gmail.com

\section{ABSTRAK}

Penerapan SIA sangat diperlukan oleh organisasi sebagai sarana untuk menunjang aktivitas operasi dan administrasi. Penelitian ini bertujuan untuk membuktikan secara empiris pengaruh kemampuan teknik personal dan IT sophistication dengan pendidikan dan pelatihan sebagai variabel moderasi pada kinerja SIA. Populasi penelitian ini adalah karyawan yang menggunakan SIA di Dinas Perindustrian dan Perdagangan Provinsi Bali. Sampel penelitian ini ditentukan berdasarkan metode non probability sampling dengan teknik sampel jenuh sehingga diperoleh pegawai negeri sipil yang menggunakan SIA di Dinas Perindustrian dan Perdagangan Provinsi Bali sebanyak 84 orang. Pengumpulan data dilakukan melalui kuesioner dan wawancara. Teknik analisis dalam penelitian ini adalah Moderated Regression Analysis (MRA). Hasil analisis menunjukkan bahwa pendidikan dan pelatihan memperkuat pengaruh kemampuan teknik personal dan IT sophistication pada kinerja SIA.

Kata Kunci: Kemampuan Teknik Personal; IT Sophistication; Pendidikan dan Pelatihan; Kinerja SIA.

\section{Education and Training Moderate The Effect of Ability Personal Techniques and IT Sophistication on AIS Performance}

\begin{abstract}
Implementation of AIS is indispensable for organizations as a means to support operational and administrative activities. This research aims to prove empirically the effect of ability personal techniques and IT sophistication with education and training as moderating variables on AIS performance. The population of this research is employees who use AIS at Dinas Perindustrian dan Perdagangan Provinsi Bali. The research sample was determined based on a non-probability sampling method with a saturated sample technique in order to obtain 84 civil servants who used AIS at Dinas Perindustrian dan Perdagangan Provinsi Bali. Data collection is done through questionnaire and interview. The analysis technique in this research is Moderated Regression Analysis (MRA). The result of analysis shows that education and training strengthen the effect of ability personal techniques and IT sophistication on AIS performance.
\end{abstract}

Keywords: Ability Personal Techniques; IT Sophistication; Education and Training; AIS Performance.

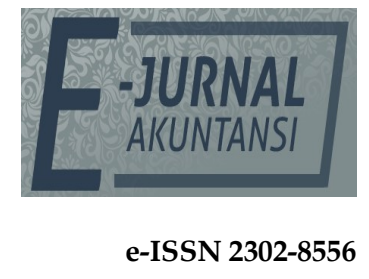

Vol. 31 No. 8

Denpasar, Agustus 2021 Hal. 2072-2085

DOI:

10.24843/EJA.2021.v31.i08.p15

PENGUTIPAN:

Utami, I G.A.P., \& Widhiyani, N.L.S. (2021). Pendidikan dan

Pelatihan Memoderasi

Pengaruh Kemampuan

Teknik Personal dan IT

Sophistication pada Kinerja SIA. E-Jurnal Akuntansi, 31(8), 2072-2085

RIWAYAT ARTIKEL: Artikel Masuk: 12 Mei 2021 Artikel Diterima: 25 Agustus 2021

Artikel dapat diakses : https://ojs.unud.ac.id/index.php/Akuntansi/index 


\section{PENDAHULUAN}

Penerapan teknologi informasi sangat diperlukan oleh suatu organisasi sebagai sarana untuk menunjang aktivitas operasi dan administrasi. Teknologi informasi akan membantu seorang manajer dalam meramal kejadian di masa mendatang, menentukan sumber daya ekonomi, serta melakukan pengawasan. Suatu organisasi membutuhkan informasi yang berkualitas. Kuntum (2019) mendefinisikan informasi sebagai data yang diproses menjadi bentuk yang lebih bermanfaat bagi penerima dan dapat digunakan untuk pengambilan keputusan. Informasi yang berkualitas dapat dihasilkan melalui pengoperasian Sistem Informasi Akuntansi (SIA). Sistem Informasi Akuntansi (SIA) dapat didefinisikan sebagai sejumlah peralatan, manusia, program komputer, dan sumber daya yang mencakup komunikasi dan koneksi jaringan bersama dengan prosedur organisasi yang memungkinkan pengumpulan, pemilahan, dan penyimpanan data informasi (MUDA, 2017). Sistem informasi akuntansi memungkinkan pelaporan yang lebih akurat, memproses sejumlah besar transaksi, dan menghasilkan pelaporan yang lebih mudah dianalisis (Lutfi et al., 2016). Ali et al., (2016) mengungkapkan bahwa terdapat keterkaitan antara pemanfaatan sistem informasi akuntansi dan kinerja organisasi. Oleh karena itu, suatu organisasi perlu memperhatikan faktor-faktor yang mempengaruhi kinerja sistem informasi akuntansi sehingga kinerja karyawan dapat tercapai dengan maksimal.

Organisasi yang berfokus pada kompetensi teknis dapat meningkatkan kinerja sistem informasi akuntansi (Madapusi \& Ortiz, 2019). Kemampuan teknik personal dapat diartikan sebagai kemampuan individu dalam mengolah data menjadi informasi yang tepat, akurat, berkualitas, serta dapat dipercaya. Tingginya kapabilitas user dalam mengoperasikan sistem informasi akuntansi akan berdampak pada kesuksesan kinerja sistem tersebut karena kemampuan personal karyawan yang tinggi dapat menghasilkan informasi yang diinginkan oleh pengguna sistem (Pradnyana \& Dharmadiaksa, 2018). Penelitian mengenai pengaruh kemampuan teknik personal pada kinerja sistem informasi akuntansi telah dilakukan pada penelitian sebelumnya, namun terjadi ketidakkonsistenan hasil penelitian. Krisnawati \& Suartana (2017), Azizah (2018), Haleem \& Teng (2018), Fatmawati et al. (2019), serta Swara \& Widhiyani (2019) menyatakan bahwa kemampuan teknik personal berpengaruh signifikan pada kinerja sistem informasi akuntansi. Berbeda dengan hasil penelitian Agustina et al. (2020), Dharmawan \& Ardianto (2017), Andhaniwati (2018), dan Unayah (2020) yang menyatakan bahwa kemampuan teknik personal tidak berpengaruh pada kinerja sistem informasi akuntansi.

Perkembangan teknologi informasi memacu organisasi untuk mengadopsi teknologi yang dapat membantu kegiatan operasional (A. L. M. Ayoobkhan \& Asirvatham, 2018). IT sophistication merupakan perkembangan teknologi informasi dengan tujuan untuk meningkatkan penerimaan, pengolahan, dan penyimpanan informasi sehingga dapat digunakan oleh pihak yang bersangkutan dalam pengambilan keputusan (Safitri \& Marlius, 2018). Sistem dengan kecanggihan informasional yang baik akan menghasilkan informasi yang cepat dan akurat. Penelitian mengenai pengaruh IT sophistication pada kinerja sistem informasi akuntansi telah dilakukan pada penelitian sebelumnya, namun terjadi ketidakkonsistenan hasil penelitian. Dharmawan \& Ardianto (2017), Nugroho et 
al. (2018), Haleem \& Raisal (2016), serta Swara \& Widhiyani (2019) memperoleh hasil bahwa IT sophistication berpengaruh positif dan signifikan pada kinerja sistem informasi akuntansi. Berbeda dengan hasil penelitian Hamta \& Putri (2019), Sasongko (2020), Sari et al. (2019), dan Ghaffar et al. (2019) yang menyatakan bahwa IT sophistication tidak berpengaruh pada efektivitas sistem informasi akuntansi.

Ketidakkonsistenan hasil penelitian sebelumnya diduga terdapat faktor lain yang menyebabkan hubungan kemampuan teknik personal dan IT sophistication dengan kinerja sistem informasi akuntansi tidak konsisten. Oleh karena itu, penelitian ini menggunakan pendidikan dan pelatihan sebagai variabel moderasi. Pendidikan dan pelatihan digunakan sebagai variabel moderasi, selain karena adanya ketidakkonsistenan pada hasil penelitian sebelumnya, pendidikan dan pelatihan digunakan dalam penelitian ini karena terkait dengan teori Technology Acceptance Model (TAM). TAM mengidentifikasi hubungan sebab akibat antara dua keyakinan utama, yaitu perceived usefulness dan perceived ease to use serta sikap, niat, dan perilaku adopsi teknologi (Ayoobkhan, 2018). Teori TAM meyakini bahwa penerapan sistem informasi akan memberikan manfaat dan kemudahan bagi pengguna dalam menyelesaikan suatu pekerjaan. Hal tersebut tentu harus didukung oleh pendidikan dan pelatihan yang memadai. Menurut Kabir et al. (2017), TAM telah ditemukan sebagai model terbaik yang menjelaskan niat individu dalam menerima dan menggunakan teknologi baru.

Berdasarkan artikel yang dilansir dari www.bali.tribunnews.com (2020), Dinas Perindustrian dan Perdagangan Provinsi Bali telah melakukan sidak ke tiga pasar di Mengwi. Saat melakukan sidak, ternyata masih banyak ditemukan penjual dan pembeli menggunakan masker tidak layak pakai bahkan tidak menggunakan masker. Oleh karena itu, Dinas Perindustrian dan Perdagangan Provinsi Bali memberikan bantuan masker kain. Selain itu, meningkatnya kebutuhan masyarakat terhadap penunjang protokol kesehatan mengakibatkan sektor kesehatan mengalami peningkatan penjualan di kala pandemi. Melihat peluang tersebut, Dinas Perindustrian dan Perdagangan Provinsi Bali melaksanakan bimbingan teknis terkait pembuatan masker kain dua lapis bagi pelaku UMKM yang terdampak COVID-19 pada 10 lokasi di Kabupaten Gianyar.

Banyaknya pengeluaran dalam mengatasi ancaman COVID-19, Dinas Perindustrian dan Perdagangan Provinsi Bali tentu harus didukung oleh sistem pengelolaan keuangan yang baik seperti SIPKD. Namun, penerapan SIPKD di Dinas Perindustrian dan Perdagangan Provinsi Bali tidak selalu berjalan efektif. Fagbemi \& Olaoye (2016) menyatakan bahwa metode akuntansi tradisional mencatat transaksi harian secara manual menjadi tidak efisien. Berdasarkan wawancara langsung dengan Kepala Sub Bagian Keuangan, tidak dapat dipungkiri bahwa masih terdapat kesalahan dalam proses penginputan transaksi. Oleh karena itu, keterampilan pegawai sangat diperlukan guna menghasilkan laporan keuangan yang andal dan relevan. Ditambah lagi, terjadi peningkatan volume transaksi untuk menunjang operasional selama pandemi. Secara tidak langsung, suatu organisasi harus mengadopsi sistem yang lebih mutakhir agar mampu mengelola volume transaksi yang kian meningkat.

Sistem informasi akuntansi pasti mengalami pembaharuan setiap saat. Proses pembaharuan sistem perlu dibarengi dengan pengembangan sumber daya manusia. Kemampuan teknik personal yang baik diperoleh dari pendidikan atau 
pengalaman dalam menggunakan sistem informasi sehingga meningkatkan kepuasan pengguna (Nurhayati et al., 2017). Pendidikan dan pelatihan pegawai seharusnya dilakukan secara berkala agar setiap perubahan pada sistem informasi dapat dikuasai oleh pengguna sistem. Namun, pendidikan dan pelatihan di Dinas Perindustrian dan Perdagangan Provinsi Bali hanya dilaksanakan sekali pada awal perekrutan pegawai. Ditambah lagi, pegawai dituntut untuk memahami penggunaan sistem informasi serta melakukan proses administrasi secara online akibat berbagai pembatasan di areal perkantoran seperti sistem shift kerja, pembatasan sosial, hingga Work From Home (WFH).

Kemampuan teknik personal merupakan kemampuan seseorang dalam mengolah data menjadi informasi yang tepat, akurat, berkualitas, serta dapat dipercaya. TAM menjelaskan bahwa terdapat dua faktor yang mempengaruhi sikap seseorang dalam menerima teknologi, yaitu perceived usefulness dan perceived ease of use. TAM menggambarkan bahwa pengguna sistem harus memiliki kemampuan teknik personal sehingga dapat mengoperasikan dan merasakan manfaat dari sistem tersebut. Semakin tinggi kemampuan teknik personal, maka semakin baik kinerja individu dan berdampak pada kinerja sistem informasi akuntansi.

Menurut Krisnawati \& Suartana (2017), semakin tinggi kemampuan teknik personal, maka mampu meningkatkan kinerja sistem informasi akuntansi. Azizah (2018) menyatakan bahwa kemampuan teknik personal berpengaruh positif dan signifikan pada kepuasan pengguna. Haleem \& Teng (2018) serta Fatmawati et al. (2019) berpendapat bahwa kemampuan pengguna berpengaruh positif pada kesuksesan sistem informasi akuntansi. Swara \& Widhiyani (2019) memperoleh hasil bahwa kemampuan teknik personal berpengaruh positif dan signifikan pada kinerja sistem informasi akuntansi.

$\mathrm{H}_{1}$ : Kemampuan teknik personal berpengaruh positif pada kinerja sistem informasi akuntansi.

IT sophistication adalah konstruksi yang mengacu pada penggunaan alam, kompleksitas dan keterkaitan teknologi informasi serta manajemen yang mampu menghasilkan sistem. TAM menjelaskan bahwa terdapat dua faktor yang mempengaruhi sikap seseorang dalam menerima teknologi, yaitu perceived usefulness dan perceived ease of use. Semakin mutakhir teknologi, maka kapasitas teknologi dalam membantu pekerjaan semakin meningkat. Hal ini dapat dilihat dari kecepatan pemrosesan data dan kualitas output yang semakin baik. Selain itu, semakin mutakhir teknologi, maka teknologi akan semakin mudah digunakan. Hal ini dapat dilihat dari teknologi yang dirancang semakin user friendly.

Swara \& Widhiyani (2019) memperoleh hasil bahwa IT sophistication berpengaruh positif dan signifikan pada kinerja sistem informasi akuntansi. Hal ini menunjukkan bahwa semakin canggih teknologi yang digunakan, maka kinerja sistem informasi akuntansi akan semakin tinggi. Nugroho et al. (2018) serta Haleem \& Raisal (2016) berpendapat bahwa teknologi informasi berpengaruh signifikan pada kinerja sistem informasi akuntansi. Dharmawan \& Ardianto (2017) menyatakan bahwa kecanggihan teknologi berpengaruh positif dan signifikan pada kinerja sistem informasi akuntansi.

$\mathrm{H}_{2}$ : IT sophistication berpengaruh positif pada kinerja sistem informasi akuntansi. 
Kemampuan teknik personal tidak akan berjalan efektif dalam pengoperasian sistem apabila tidak didukung oleh pendidikan dan pelatihan yang memadai (Puspitasari \& Juliarsa, 2017). Penelitian Turnip \& Suardikha (2018) menunjukkan bahwa pendidikan dan pelatihan berpengaruh positif dan signifikan terhadap efektivitas sistem informasi akuntansi. Pendidikan dan pelatihan dapat memberikan keterampilan dalam penggunaan sistem sehingga kinerja sistem informasi akuntansi menjadi lebih efektif. Penelitian Suartika \& Widhiyani (2017) menyatakan bahwa pendidikan dan pelatihan mampu memoderasi pengaruh kemampuan teknik personal pada kinerja sistem informasi akuntansi.

Beberapa penelitian terdahulu menunjukkan hasil yang tidak konsisten mengenai pengaruh kemampuan teknik personal pada kinerja sistem informasi akuntansi. Krisnawati \& Suartana (2017), Azizah (2018), Haleem \& Teng (2018), Fatmawati et al. (2019), serta Swara \& Widhiyani (2019) menyatakan bahwa kemampuan teknik personal berpengaruh positif dan signifikan pada kinerja sistem informasi akuntansi. Berbeda dengan hasil penelitian Agustina et al. (2020), Dharmawan \& Ardianto (2017), Andhaniwati (2018), dan Unayah (2020) yang menyatakan bahwa kemampuan teknik personal tidak berpengaruh pada kinerja sistem informasi akuntansi.

$\mathrm{H}_{3}$ : Pendidikan dan pelatihan memperkuat pengaruh kemampuan teknik personal pada kinerja sistem informasi akuntansi.

Semutakhir apapun teknologi yang digunakan, karyawan dapat mengoperasikan sistem informasi jika didukung oleh pendidikan dan pelatihan. Penelitian Mahardika \& Suardhika (2018) menunjukkan bahwa pendidikan dan pelatihan berpengaruh positif dan signifikan terhadap efektivitas penggunaan sistem informasi akuntansi. Pendidikan dan pelatihan dapat memberikan keterampilan dalam penggunaan sistem sehingga kinerja sistem informasi akuntansi menjadi lebih efektif. Penelitian Widiantari \& Mertha (2018) menyatakan bahwa pendidikan dan pelatihan mampu memoderasi pengaruh teknologi informasi pada kinerja sistem informasi akuntansi.

Beberapa penelitian terdahulu menunjukkan hasil yang tidak konsisten mengenai pengaruh IT sophistication pada kinerja sistem informasi akuntansi. Swara \& Widhiyani (2019), Nugroho et al. (2018), Haleem \& Raisal (2016), serta Dharmawan \& Ardianto (2017) menyatakan bahwa IT sophistication berpengaruh positif dan signifikan pada kinerja sistem informasi akuntansi. Berbeda dengan hasil penelitian Hamta \& Putri (2019), Sasongko (2020), dan Sari et al. (2019) yang menyatakan bahwa IT sophistication tidak berpengaruh terhadap efektivitas sistem informasi akuntansi. Ghaffar et al. (2019) juga memperoleh hasil bahwa teknologi tidak berpengaruh signifikan pada penggunaan e-accounting.

$\mathrm{H}_{4}$ : Pendidikan dan pelatihan memperkuat pengaruh IT sophistication pada kinerja sistem informasi akuntansi.

\section{METODE PENELITIAN}

Pendekatan yang digunakan dalam penelitian ini adalah pendekatan kuantitatif berbentuk asosiatif. Penelitian ini dilakukan pada Dinas Perindustrian dan Perdagangan Provinsi Bali yang beralamat di Jl. Raya Puputan-Komplek Nitimandala, Denpasar, Bali. Objek dalam penelitian ini adalah kinerja sistem 
informasi akuntansi $(\mathrm{Y})$, kemampuan teknik personal $\left(\mathrm{X}_{1}\right)$, IT sophistication $\left(\mathrm{X}_{2}\right)$, serta pendidikan dan pelatihan $\left(\mathrm{X}_{3}\right)$.

Penelitian ini menggunakan variabel dependen, yaitu kinerja sistem informasi akuntansi (Y). Kinerja sistem informasi akuntansi adalah kemampuan sistem dalam menghasilkan informasi untuk mencapai tujuan tertentu. Indikator pengukuran kinerja sistem informasi akuntansi diantaranya kepuasan pengguna dan pemakaian sistem informasi akuntansi. Penelitian ini menggunakan variabel independen, yaitu kemampuan teknik personal $\left(\mathrm{X}_{1}\right)$ dan IT sophistication $\left(\mathrm{X}_{2}\right)$. Kemampuan teknik personal merupakan kemampuan seseorang dalam mengolah data menjadi informasi yang tepat, akurat, berkualitas, serta dapat dipercaya. Indikator pengukuran kemampuan teknik personal diantaranya pengetahuan, kemampuan, dan keahlian. IT sophistication adalah perkembangan teknologi informasi dengan tujuan untuk meningkatkan penerimaan, pengolahan, dan penyimpanan informasi sehingga dapat digunakan oleh pihak yang bersangkutan dalam pengambilan keputusan. Indikator pengukuran IT sophistication diantaranya kecanggihan teknologi, informasi, dan fungsional. Penelitian ini menggunakan variabel moderasi, yaitu pendidikan dan pelatihan $\left(X_{3}\right)$. Pendidikan dimaksudkan untuk meningkatkan pengetahuan yang bersifat teoritis, sedangkan pelatihan dimaksudkan untuk meningkatkan keahlian yang bersifat praktis. Indikator pengukuran pendidikan dan pelatihan diantaranya pelaksanaan serta keuntungan program pendidikan dan pelatihan.

Sumber data yang digunakan dalam penelitian ini adalah data primer dan sekunder. Data primer adalah data yang langsung diberikan pemberi data kepada pengumpul data (Sugiyono, 2018:219). Data primer berupa jawaban dari responden atas pernyataan kuesioner yang disebarkan oleh peneliti. Data sekunder adalah data yang tidak langsung diberikan pemberi data kepada pengumpul data (Sugiyono, 2018:219). Data sekunder berupa sejarah dan struktur organisasi Dinas Perindustrian dan Perdagangan Provinsi Bali.

Populasi dalam penelitian ini adalah seluruh karyawan yang menggunakan sistem informasi akuntansi di Dinas Perindustrian dan Perdagangan Provinsi Bali. Teknik penetapan sampel yang digunakan dalam penelitian ini adalah teknik sampel jenuh. Sampel jenuh adalah teknik penentuan sampel bila semua anggota populasi dijadikan sampel, hal ini dilakukan bila jumlah populasi relatif kecil, kurang dari 30 (Sugiyono, 2018:145). Hal ini terjadi pada Dinas Perindustrian dan Perdagangan Provinsi Bali yang memiliki jumlah populasi relatif kecil, yaitu seluruh pegawai negeri sipil yang menggunakan sistem informasi akuntansi terkomputerisasi di Dinas Perindustrian dan Perdagangan Provinsi Bali sebanyak 84 orang.

Metode pengumpulan data yang digunakan dalam penelitian ini adalah kuesioner dan wawancara. Menurut Sugiyono (2018:142), kuesioner merupakan teknik pengumpulan data yang dilakukan dengan cara memberi seperangkat pertanyaan atau pernyataan tertulis kepada responden untuk dijawab. Kuesioner dalam penelitian ini diukur menggunakan skala likert modifikasi dengan skor 1 sampai 4. Menurut Sugiyono (2018:140), wawancara adalah percakapan dengan maksud tertentu yang dilakukan oleh dua pihak, yaitu pewawancara (interview) yang mengajukan pertanyaan dan yang diwawancarai (interviewer) untuk memberikan jawaban atas pertanyaan yang diberikan. Wawancara dilakukan 
untuk mengetahui sistem informasi akuntansi yang digunakan oleh karyawan dan jumlah karyawan yang menggunakan sistem informasi akuntansi di Dinas Perindustrian dan Perdagangan Provinsi Bali. Penelitian ini menggunakan dua variabel independen dan satu variabel moderasi, oleh karena itu metode analisis data yang digunakan adalah Moderated Regression Analysis (MRA). MRA merupakan aplikasi dari regresi berganda dimana dalam persamaan regresinya mengandung unsur interaksi. MRA dinyatakan dalam persamaan sebagai berikut. $Y=\alpha+\beta_{1} X_{1}+\beta_{2} X_{2}+\beta_{3} X_{3}+\beta_{4} X_{1} X_{3}+\beta_{5} X_{2} X_{3}+\varepsilon$

Keterangan :

Y

a

$\beta_{1}, \beta_{2}, \beta_{3}, \beta_{4}, \beta_{5}$

$\mathrm{X}_{1}$

$X_{2}$

$X_{3}$

$\mathrm{X}_{1} \mathrm{X}_{3}$

$\mathrm{X}_{2} \mathrm{X}_{3}$

$\varepsilon$
= Kinerja Sistem Informasi Akuntansi

= Konstanta

= Nilai Koefisien Regresi Berganda

$=$ Kemampuan Teknik Personal

= Information Technology Sophistication

$=$ Pendidikan dan Pelatihan

$=$ Interaksi antara kemampuan teknik personal dengan pendidikan dan pelatihan

$=$ Interaksi antara information technology sophistication dengan pendidikan dan pelatihan

$=$ Nilai Residu

\section{HASIL DAN PEMBAHASAN}

Pengaruh kemampuan teknik personal dan IT sophistication pada kinerja sistem informasi akuntansi dengan pendidikan dan pelatihan sebagai variabel moderasi dianalisis menggunakan uji t. Hubungan masing-masing variabel bebas signifikan mempengaruhi variabel terikat jika nilai Sig. $t_{\text {hitung }} \leq 0,05$, sebaliknya hubungan masing-masing variabel bebas tidak signifikan mempengaruhi variabel terikat jika nilai Sig. $t_{\text {hitung }}>0,05$. Hasil uji regresi moderasi diperoleh dengan bantuan SPSS 21 for windows. Tabel 1, menyajikan hasil uji MRA pada penelitian ini.

Tabel 1. Hasil Uji Moderated Regression Analysis (MRA)

\begin{tabular}{|c|c|c|c|c|c|}
\hline \multirow[t]{2}{*}{ Model } & \multicolumn{2}{|c|}{$\begin{array}{l}\text { Unstandardized } \\
\text { Coefficients }\end{array}$} & \multirow{2}{*}{$\begin{array}{c}\text { Standardized } \\
\text { Coefficients }\end{array}$} & \multirow[t]{2}{*}{$\mathrm{t}$} & \multirow[t]{2}{*}{ Sig. } \\
\hline & B & Std. Error & & & \\
\hline (Constant) & 7,219 & 7,553 & & 0,956 & 0,342 \\
\hline$X_{1}$ & 0,681 & 0,400 & 1,590 & 2,703 & 0,013 \\
\hline $\mathrm{X}_{2}$ & 1,016 & 0,422 & 2,024 & 2,408 & 0,018 \\
\hline$X_{3}$ & 0,860 & 0,585 & 1,242 & 2,469 & 0,006 \\
\hline $\mathrm{X}_{1} \mathrm{X}_{3}$ & 0,044 & 0,030 & 2,251 & 4,452 & 0,000 \\
\hline$X_{2} X_{3}$ & 0,088 & 0,031 & 4,083 & 2,787 & 0,007 \\
\hline
\end{tabular}

Sumber: Data Penelitian, 2021

Berdasarkan hasil koefisien regresi pada Tabel 1, maka dapat disusun model persamaan MRA sebagai berikut.

$$
Y=7,219+0,681 X_{1}+1,016 X_{2}+0,860 X_{3}+0,044 X_{1} X_{3}+0,088 X_{2} X_{3}+\varepsilon
$$

Perhitungan SPSS menghasilkan nilai signifikansi kemampuan teknik personal $\left(\mathrm{X}_{1}\right)$ sebesar 0,013 kurang dari nilai signifikansi yang ditetapkan $(0,013<$ $0,05)$ mengindikasikan $\mathrm{H}_{0}$ ditolak dan $\mathrm{H}_{1}$ diterima, sedangkan nilai koefisien regresi sebesar 0,681 mengindikasikan ke arah positif. Hasil ini memiliki arti 
kemampuan teknik personal berpengaruh positif pada kinerja sistem informasi akuntansi.

Nilai signifikansi IT sophistication $\left(\mathrm{X}_{2}\right)$ sebesar 0,018 kurang dari nilai signifikansi yang ditetapkan $(0,018<0,05)$ mengindikasikan $\mathrm{H}_{0}$ ditolak dan $\mathrm{H}_{2}$ diterima, sedangkan nilai koefisien regresi sebesar 1,016 mengindikasikan ke arah positif. Hasil ini memiliki arti IT sophistication berpengaruh positif pada kinerja sistem informasi akuntansi.

Nilai signifikansi pendidikan dan pelatihan $\left(X_{3}\right)$ sebesar 0,006 $(0,006<0,05)$ dan interaksi kemampuan teknik personal dengan pendidikan dan pelatihan $\left(\beta_{4}\right)$ sebesar 0,000 $(0,000<0,05)$ mengindikasikan $\mathrm{H}_{0}$ ditolak dan $\mathrm{H}_{3}$ diterima, sedangkan nilai koefisien regresi interaksi kemampuan teknik personal dengan pendidikan dan pelatihan sebesar 0,044 mengindikasikan efek moderasi bernilai positif. Hasil ini memiliki arti pendidikan dan pelatihan memperkuat pengaruh kemampuan teknik personal pada kinerja sistem informasi akuntansi.

Nilai signifikansi pendidikan dan pelatihan $\left(\mathrm{X}_{3}\right)$ sebesar 0,006 $(0,006<0,05)$ dan interaksi IT sophistication dengan pendidikan dan pelatihan $\left(\beta_{5}\right)$ sebesar 0,007 $(0,007<0,05)$ mengindikasikan $\mathrm{H}_{0}$ ditolak dan $\mathrm{H}_{4}$ diterima. sedangkan nilai koefisien regresi interaksi IT sophistication dengan pendidikan dan pelatihan sebesar 0,088 mengindikasikan efek moderasi bernilai positif. Hasil ini memiliki arti pendidikan dan pelatihan memperkuat pengaruh IT sophistication pada kinerja sistem informasi akuntansi.

Nilai $\mathrm{R}^{2}$ digunakan untuk mengukur seberapa besar variabel independen mampu menjelaskan perubahan variabel dependen. Berdasarkan nilai $\mathrm{R}^{2}$ dapat diketahui berapa persen variabel dependen dapat dijelaskan oleh variabel independen, sedangkan sisanya dijelaskan oleh variabel lain di luar model. Tabel 2 , menyajikan nilai $\mathrm{R}^{2}$ pada penelitian ini.

Tabel 2. Koefisien Determinasi $\left(\mathbf{R}^{2}\right)$

\begin{tabular}{ccccc}
\hline Model & $\mathrm{R}$ & $R$ Square & $\begin{array}{c}\text { Adjusted } R \\
\text { Square }\end{array}$ & $\begin{array}{c}\text { Std. Error of the } \\
\text { Estimate }\end{array}$ \\
\hline 1 & $0,723^{\mathrm{a}}$ & 0,522 & 0,468 & 2,050 \\
\hline
\end{tabular}

Sumber: Data Penelitian, 2021

Berdasarkan Tabel 2, dapat diketahui bahwa nilai Adjusted $R^{2}$ sebesar 0,468. Hal ini berarti bahwa 46,8 persen variasi kinerja sistem informasi akuntansi mampu dijelaskan oleh kemampuan teknik personal, IT sophistication, interaksi kemampuan teknik personal dengan pendidikan dan pelatihan, serta interaksi IT sophistication dengan pendidikan dan pelatihan, sedangkan sisanya sebesar 53,2 persen dijelaskan oleh faktor lain di luar model penelitian.

Tabel 3. Hasil Uji Kelayakan Model (Uji F)

\begin{tabular}{llccccc}
\hline Model & $\begin{array}{c}\text { Sum of } \\
\text { Squares }\end{array}$ & Df & $\begin{array}{c}\text { Mean } \\
\text { Square }\end{array}$ & F & Sig. \\
\hline \multirow{2}{*}{1} & Regression & 12,748 & 5 & 2,550 & 10,254 & $0,000^{\mathrm{b}}$ \\
Residual & 87,538 & 78 & 1,122 & & \\
Total & 100,286 & 83 & & & \\
\hline
\end{tabular}

Sumber: Data Penelitian, 2021

Uji F digunakan untuk mengetahui kelayakan model regresi linear berganda sebagai alat analisis yang menguji pengaruh variabel independen terhadap variabel dependen. Uji F dilakukan dengan melihat nilai signifikan pada Tabel 
ANOVA model dikatakan layak atau variabel bebas mampu menjelaskan variabel terikat apabila nilai signifikansi ANOVA $\leq a=0,05$. Tabel 3, menyajikan hasil uji F pada penelitian ini.

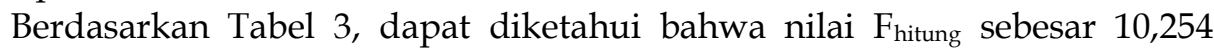
dengan signifikansi sebesar $0,000 \leq a=0,05$. Hal ini berarti kelompok yang diuji memiliki perbedaan yang signifikan. Kemampuan teknik personal $\left(\mathrm{X}_{1}\right)$, IT sophistication $\left(\mathrm{X}_{2}\right)$, interaksi kemampuan teknik personal dengan pendidikan dan pelatihan $\left(\mathrm{X}_{1} \mathrm{X}_{3}\right)$, serta interaksi IT sophistication dengan pendidikan dan pelatihan $\left(\mathrm{X}_{2} \mathrm{X}_{3}\right)$ secara simultan berpengaruh signifikan pada kinerja sistem informasi akuntansi $(Y)$ sehingga model penelitian layak digunakan sebagai model regresi.

Uji $\mathrm{t}$ menunjukkan seberapa jauh variabel independen secara parsial berpengaruh signifikan terhadap variabel dependen (Ghozali, 2016:98). $\mathrm{H}_{0}$ diterima apabila tingkat signifikansi $\mathrm{t}>\mathrm{a}=0,05$, sebaliknya $\mathrm{H}_{1}$ diterima apabila tingkat signifikansi $\mathrm{t} \leq \mathrm{a}=0,05$. Tabel 4 , menyajikan hasil uji $\mathrm{t}$ pada penelitian ini. Tabel 4. Hasil Uji Hipotesis (Uji t)

\begin{tabular}{cccccc}
\hline \multirow{2}{*}{ Model } & \multicolumn{2}{c}{$\begin{array}{c}\text { Unstandardized } \\
\text { Coefficients }\end{array}$} & $\begin{array}{c}\text { Standardized } \\
\text { Coefficients }\end{array}$ & $\mathrm{t}$ & Sig. \\
\cline { 2 - 3 } & $\mathrm{B}$ & Std. Error & Beta & & \\
\hline (Constant) & 7,219 & 7,553 & & 0,956 & 0,342 \\
$\mathrm{X}_{1}$ & 0,681 & 0,400 & 1,590 & 2,703 & 0,013 \\
$\mathrm{X}_{2}$ & 1,016 & 0,422 & 2,024 & 2,408 & 0,018 \\
$\mathrm{X}_{3}$ & 0,860 & 0,585 & 1,242 & 2,469 & 0,006 \\
$\mathrm{X}_{1} \mathrm{X}_{3}$ & 0,044 & 0,030 & 2,251 & 4,452 & 0,000 \\
$\mathrm{X}_{2} \mathrm{X}_{3}$ & 0,088 & 0,031 & 4,083 & 2,787 & 0,007 \\
\hline
\end{tabular}

Sumber : Data Penelitian, 2021

Berdasarkan Tabel 4, dapat diketahui bahwa kemampuan teknik personal $\left(X_{1}\right)$ memiliki nilai signifikansi sebesar 0,013 . Nilai signifikansi $\beta_{1}<0,05$ dan $\beta_{1}$ bernilai positif mengindikasikan bahwa $\mathrm{H}_{0}$ ditolak dan $\mathrm{H}_{1}$ diterima. Hasil ini memiliki arti kemampuan teknik personal berpengaruh positif pada kinerja sistem informasi akuntansi. IT sophistication $\left(\mathrm{X}_{2}\right)$ memiliki nilai signifikansi sebesar 0,018. Nilai signifikansi $\beta_{2}<0,05$ dan $\beta_{2}$ bernilai positif mengindikasikan bahwa $\mathrm{H}_{0}$ ditolak dan $\mathrm{H}_{2}$ diterima. Hasil ini memiliki arti IT sophistication berpengaruh positif pada kinerja sistem informasi akuntansi.

Pendidikan dan pelatihan $\left(\beta_{3}\right)$ memiliki nilai signifikansi sebesar 0,006 (significant). Hal ini mengindikasikan variabel moderasi merupakan tipe moderasi semu (quasi moderator). Interaksi kemampuan teknik personal dengan pendidikan dan pelatihan memiliki nilai signifikansi sebesar 0,000. Nilai signifikansi $\beta_{4}<0,05$ dan $\beta_{4}$ bernilai positif mengindikasikan bahwa $\mathrm{H}_{0}$ ditolak dan $\mathrm{H}_{3}$ diterima. Hasil ini memiliki arti pendidikan dan pelatihan memperkuat pengaruh kemampuan teknik personal pada kinerja sistem informasi akuntansi. Pendidikan dan pelatihan $\left(\beta_{3}\right)$ memiliki nilai signifikansi sebesar 0,006 (significant). Hal ini mengindikasikan variabel moderasi merupakan tipe moderasi semu (quasi moderator). Interaksi IT sophistication dengan pendidikan dan pelatihan memiliki nilai signifikansi sebesar 0,007 . Nilai signifikansi $\beta_{5}<0,05$ dan $\beta_{5}$ bernilai positif mengindikasikan bahwa $\mathrm{H}_{0}$ ditolak dan $\mathrm{H}_{4}$ diterima. Hasil ini memiliki arti pendidikan dan pelatihan memperkuat pengaruh IT sophistication pada kinerja sistem informasi akuntansi. 
Hipotesis pertama $\left(\mathrm{H}_{1}\right)$ menyatakan bahwa kemampuan teknik personal berpengaruh positif pada kinerja sistem informasi akuntansi. Hal ini berarti bahwa semakin tinggi kemampuan teknik personal yang dimiliki oleh pegawai menyebabkan kinerja sistem informasi akuntansi di Dinas Perindustrian dan Perdagangan Provinsi Bali mengalami peningkatan. Kemampuan teknik personal yang tinggi menyebabkan pengguna merasakan manfaat dan memahami pengoperasian dari sistem informasi tersebut. Pengguna yang memiliki keterampilan lebih dalam pengoperasian sistem dapat memperoleh informasi yang mendukung tugas-tugas dalam organisasi sehingga kinerja karyawan dapat tercapai dengan maksimal.

Hasil penelitian ini mendukung penelitian dari Krisnawati \& Suartana (2017), Azizah (2018), Haleem \& Teng (2018), Fatmawati et al. (2019), serta Swara \& Widhiyani (2019) yang menyatakan bahwa kemampuan teknik personal berpengaruh positif dan signifikan pada kinerja sistem informasi akuntansi. Semakin tinggi kemampuan teknik personal, maka mampu meningkatkan kinerja sistem informasi akuntansi. Hasil penelitian ini mengacu pada teori Technology Acceptance Model (TAM). TAM mampu menjelaskan bahwa seseorang yang memiliki kemampuan teknik mempercayai bahwa suatu sistem sangat mudah dioperasikan tanpa membutuhkan usaha yang keras karena pengguna telah mengetahui cara pengoperasian serta kemudahan pemakaian dari sistem tersebut.

Hipotesis kedua $\left(\mathrm{H}_{2}\right)$ menyatakan bahwa IT sophistication berpengaruh positif pada kinerja sistem informasi akuntansi. Hal ini berarti bahwa semakin tinggi IT sophistication dari sistem informasi menyebabkan kinerja sistem informasi akuntansi di Dinas Perindustrian dan Perdagangan Provinsi Bali mengalami peningkatan. Kecanggihan teknologi yang tinggi menyebabkan pemrosesan data menjadi informasi semakin cepat dan akurat. Kecepatan pemrosesan data akan meningkatkan produktivitas dalam menyelesaikan suatu pekerjaan sehingga kinerja sistem informasi akuntansi akan berjalan efektif.

Hasil penelitian ini mendukung penelitian dari Swara \& Widhiyani (2019), Nugroho et al. (2018), Haleem \& Raisal (2016), serta Dharmawan \& Ardianto (2017) yang menyatakan bahwa IT sophistication berpengaruh positif dan signifikan pada kinerja sistem informasi akuntansi. Semakin canggih teknologi yang digunakan, maka kinerja sistem informasi akuntansi yang dihasilkan akan semakin tinggi. Hasil penelitian ini mengacu pada teori Technology Acceptance Model (TAM). TAM mampu menjelaskan bahwa semakin canggih sebuah teknologi, maka semakin mudah individu dalam menggunakan teknologi tersebut.

Hipotesis ketiga $\left(\mathrm{H}_{3}\right)$ menyatakan bahwa pendidikan dan pelatihan memperkuat pengaruh kemampuan teknik personal pada kinerja sistem informasi akuntansi. Hal ini berarti bahwa pengaruh kemampuan teknik personal pada kinerja sistem informasi akuntansi di Dinas Perindustrian dan Perdagangan Provinsi Bali akan mengalami peningkatan apabila didukung oleh program pendidikan dan pelatihan yang memadai. Kemampuan personal yang tinggi dapat membantu individu dalam menyesuaikan diri dengan perkembangan teknologi saat ini. Apabila pendidikan dan pelatihan mengalami peningkatan, maka pegawai akan lebih mudah dalam mengoperasikan sistem dan menyelesaikan suatu pekerjaan sehingga kinerja sistem informasi akuntansi juga akan meningkat. 
Hasil penelitian ini mendukung penelitian dari Suartika \& Widhiyani (2017) yang menyatakan bahwa pendidikan dan pelatihan mampu memoderasi pengaruh kemampuan teknik personal pada kinerja sistem informasi akuntansi. Semakin baik program pendidikan dan pelatihan yang diberikan kepada pegawai, maka pengaruh kemampuan teknik personal pada kinerja sistem informasi akuntansi akan meningkat. Hasil penelitian ini mengacu pada teori Technology Acceptance Model (TAM). TAM meyakini bahwa pemakaian sistem informasi akan memberikan manfaat dan kemudahan bagi pengguna dalam menyelesaikan suatu pekerjaan. Hal tersebut tentu harus didukung oleh pendidikan dan pelatihan yang memadai dari pengguna sistem.

Hipotesis keempat $\left(\mathrm{H}_{4}\right)$ menyatakan bahwa pendidikan dan pelatihan memperkuat pengaruh IT sophistication pada kinerja sistem informasi akuntansi. Hal ini berarti bahwa pengaruh IT sophistication pada kinerja sistem informasi akuntansi di Dinas Perindustrian dan Perdagangan Provinsi Bali akan mengalami peningkatan apabila didukung oleh program pendidikan dan pelatihan yang memadai. Sistem dengan kecanggihan informasional yang baik akan membantu organisasi dalam menghasilkan informasi yang cepat dan akurat. Semakin mutakhir sebuah teknologi, maka kapasitas teknologi dalam membantu pekerjaan manusia semakin meningkat. Hal tersebut tentu harus didukung oleh pendidikan dan pelatihan yang memadai.

Hasil penelitian ini mendukung penelitian dari Widiantari \& Mertha (2018) yang menyatakan bahwa pendidikan dan pelatihan mampu memoderasi pengaruh IT sophistication pada kinerja sistem informasi akuntansi. Semakin baik program pendidikan dan pelatihan yang diberikan kepada pegawai, maka pengaruh IT sophistication pada kinerja sistem informasi akuntansi akan mengalami peningkatan. Hasil penelitian ini mengacu pada teori Technology Acceptance Model (TAM). TAM meyakini bahwa pemakaian sistem informasi akan memberikan manfaat dan kemudahan bagi pengguna dalam menyelesaikan suatu pekerjaan. Hal tersebut tentu harus didukung oleh pendidikan dan pelatihan yang memadai dari pengguna sistem.

\section{SIMPULAN}

Penelitian ini memberikan hasil analisis mengenai faktor-faktor yang mempengaruhi kinerja sistem informasi akuntansi di Dinas Perindustrian dan Perdagangan Provinsi Bali. Hasil uji hipotesis menunjukkan bahwa pendidikan dan pelatihan memperkuat pengaruh kemampuan teknik personal dan IT sophistication pada kinerja sistem informasi akuntansi di Dinas Perindustrian dan Perdagangan Provinsi Bali. Hasil penelitian ini sesuai dengan kajian teori khususnya teori Technology Acceptance Model (TAM) dan beberapa penelitian terdahulu.

Dinas Perindustrian dan Perdagangan Provinsi Bali perlu memperhatikan faktor-faktor yang mempengaruhi kinerja sistem informasi akuntansi diantaranya kemampuan teknik personal, IT sophistication, serta pendidikan dan pelatihan. IT sophistication yang diterapkan pada sistem informasi akuntansi di Dinas Perindustrian dan Perdagangan Provinsi Bali masih tergolong rendah. Oleh karena itu, IT sophistication dari sistem informasi akuntansi yang diterapkan pada Dinas Perindustrian dan Perdagangan Provinsi Bali perlu dilakukan 
pengembangan lebih lanjut sehingga menghasilkan informasi yang cepat dan akurat.

\section{REFERENSI}

Agustina, R., Masrifani, \& Suri, V. A. R. (2020). Pengaruh Kemampuan Teknik Personal dan Partisipasi Pemakai Sistem Informasi terhadap Kinerja Sistem Informasi Akuntansi pada ULP PLN Wilayah Banjarmasin. Jurnal Ekonomi dan Bisnis (DINAMIKA EKONOMI), 13(2), hal. 380-393.

Ali, B. J. A., Omar, W. A. W., \& Bakar, R. (2016). Accounting Information System (AIS) and Organizational Performance : Moderating Effect of Organizational Culture. International Journal of Economics, Commerce, and Management, 4:4, pp. 138-158. https:/ / doi.org/10.21859/eulawrev-08061

Andhaniwati, E. (2018). Pengaruh Partisipasi Pemakai, Kemampuan Teknik Personal Sistem Informasi, Dukungan Manajemen Puncak terhadap Keberhasilan Pengembangan Sistem Informasi Akuntansi pada PT. PLN APJ Madiun. Jurnal Akuntansi Jaya Negara, 10(1), hal. 64-71.

Ayoobkhan, A. (2018). Factors Contributing to The Adoption of Mobile Banking in Sri Lanka : Special Reference to Sampath Bank in Ampara District. International Journal of Latest Engineering and Management Research (IJLEMR), 3:8, pp. 47-57.

Ayoobkhan, A. L. M., \& Asirvatham, D. (2018). A Study on The Adoption of Software as a Service (SaaS) in Online Business SMEs in Sri Lanka. Asian Journal of Research in Computer Science, 2:2, pp. 1-13. https://doi.org/10.9734/AJRCOS/2018/45904

Azizah, S. N. (2018). Analysis of Factors Affecting Application of Computer-Based Accounting Information System on Banking Sector. Advances in Social Science, Education, and Humanities Research, 23:1, pp. 382-385. https://doi.org/10.2991/amca-18.2018.105

Dharmawan, J., \& Ardianto, J. (2017). Pengaruh Kemutakhiran Teknologi, Kemampuan Teknik Personal Sistem Informasi, Program Pelatihan Pengguna, dan Dukungan Manajemen Puncak terhadap Kinerja Sistem Informasi Akuntansi (Studi Empiris pada Karyawan Perusahaan Retail Consumer Goods Wilayah Tangerang. Ultima Accounting, 9(1), hal. 60-78. https://doi.org/10.31937/akuntansi.v9i1.588

Fagbemi, T. O., \& Olaoye, J. A. (2016). An Evaluation of Accounting Information System and Performance of Small Scale Enterprises in Kwara State, Nigeria. DBA African Management Review, 6:1, pp. 1-16.

Fatmawati, I., Cahyono, D., \& Maharani, A. (2019). Pengaruh Partisipasi Pemakai Sistem Informasi, Kemampuan Pemakai Sistem Informasi, Ukuran Organisasi terhadap Kinerja Sistem Informasi Akuntansi. International Journal of Social Science and Business, 3(1), hal. 11-19. https://doi.org/10.23887/ijssb.v3i1.17159

Ghaffar, A. M., Mokhtar, M. Z., Ismail, W. N. S. W., \& Othman, M. R. (2019). Determinant of E-Accounting (EA) Adoption among Malaysian Maritime SMES. International Journal of Engineering and Technology, 8:18, pp. 102-105.

Ghozali, I. (2016). Aplikasi Analisis Multivariate dengan Program SPSS. Semarang : Badan Penerbit Universitas Diponegoro. 
Haleem, A., \& Raisal, I. (2016). The Study of The Influence of Information Technology Sophistication on The Quality of Accounting Information System in Bank Branches at Ampara District, Sri Lanka, pp. 114-124.

Haleem, A., \& Teng, K. L. L. (2018). Impact of User Competency on Accounting Information System Success: Banking Sectors in Sri Lanka. International Journal of Economics and Financial Issues, 8:6, pp. 167-175. https://doi.org/https://doi.org/10.32479/ijefi.7212

Hamta, F., \& Putri, R. S. A. (2019). Pengaruh Kecanggihan Teknologi Informasi, Partisipasi Manajemen, dan Kemampuan Teknik Pemakai Sistem Informasi Akuntansi pada Kinerja Individu Karyawan PT. Batamec. Jurnal Akuntansi Measurement, 13(2), hal. 156-163.

Kabir, M. A., Saidin, S. Z., \& Ahmi, A. (2017). An Examination of Factors that Influence Employees' Behavioral Intention to Use Electronic Revenue Collection System in Public Hospitals. Journal of Telecommunication, Electronic, and Computer Engineering, 9:12, pp. 109-114.

Krisnawati, N. P. A., \& Suartana, I. W. (2017). Pengaruh Kompetensi Karyawan, Motivasi Kerja, Komitmen Organisasi, Kemampuan Teknik Personal terhadap Kinerja Sistem Informasi Akuntansi. E-Jurnal Akuntansi Universitas Udayana, 21(3), hal. 2539-2566. https://doi.org/10.24843/EJA.2017.v20.i03.p30

Kuntum, C. (2019). Effect of Implementation of Enterprise Resource Planning System on Quality of Accounting Information. Russian Journal of Agricultural and Socio-Economic Sciences, 3:87, pp. 15-20. https://doi.org/10.18551/rjoas.2019-03.03

Lutfi, A. A., Idris, K. M., \& Mohamad, R. (2016). The Influence of Technological, Organizational, and Environmental Factors on Accounting Information System Usage among Jordanian Small and Medium-Sized Enterprises. International Journal of Economics and Financial Issues, 6:7, pp. 240-248.

Madapusi, A., \& Ortiz, D. A. C. (2019). The Influence of Technical Competence Factors in ERP System Implementations. American Journal of Business, 10:2, pp. 27-39.

Mahardika, I. B. G. A., \& Suardhika, I. M. S. (2018). Analisis Faktor-Faktor yang Mempengaruhi Kinerja Sistem Informasi Akuntansi pada BPR di Kota Denpasar. E-Jurnal Akuntansi Universitas Udayana, 24(3), hal. 2073-2095. https:/ / doi.org/10.24843/eja.2018.v24.i03.p16

Muda, I. (2017). User Impact of Literacy on Treatment Outcomes Quality Regional Financial Information System. Management Dynamics in The Knowledge Economy, 5:2, pp. 307-326. https:// doi.org/10.25019/mdke/5.2.08

Nugroho, A. A., Astuti, D. S. P., \& Kristianto, D. (2018). Pengaruh Teknologi Informasi, Kemampuan Teknik Pemakai, Dukungan Manajemen Puncak, dan Kompleksitas Tugas terhadap Kinerja Sistem Informasi Akuntansi. Jurnal Akuntansi dan Sistem Teknologi Informasi, 14(4), hal. 507-518.

Nurhayati, N., Iss, A., \& Sk, R. (2017). The Influence of Personal Information Capability and Management Commitment on The Success of The Implementation of Accounting Information System in Baznas of District / City Level in West Java Province. International Journal of Advanced Engineering, Management, and Science (IJAEMS), 3:7, pp. 803-810. 
https://doi.org/10.24001/ijaems.3.7.13

Pradnyana, I. G. M. A., \& Dharmadiaksa, I. B. (2018). Pengaruh Kemampuan Personal, Pelatihan Kerja, dan Keterlibatan Pemakai terhadap Kinerja Sistem Informasi Akuntansi. E-Jurnal Akuntansi Universitas Udayana, 25(2), hal. 14181447. https:// doi.org/10.24843/ eja.2018.v25.i02.p23

Puspitasari, N. W. N., \& Juliarsa, G. (2017). Keterlibatan dan Kemampuan Teknik Personal pada Kinerja SIA dengan Pendidikan dan Pelatihan sebagai Variabel Moderasi. E-Jurnal Akuntansi Universitas Udayana, 20(1), hal. 380408.

Safitri, R. N., \& Marlius, D. (2018). Penerapan E-Banking dalam Meningkatkan Jasa dan Layanan Perbankan di PT. Bank Rakyat Indonesia Cabang Padang. hal. 1-9. https:// doi.org/10.31227/osf.io/gkv8t

Sari, G. A. M. K. N., Mendra, N. P. Y., \& Adiyadnya, M. S. P. (2019). Pengaruh Kecanggihan Teknologi Informasi, Partisipasi Manajemen, dan Kemampuan Teknik Pemakai SIA terhadap Efektivitas SIA pada Main Office of Krisna Holding Company. Seminar Nasional INOBALI 2019 (Inovasi Baru dalam Penelitian Sains, Teknologi, dan Humaniora), hal. 696-703.

Sasongko, D. A. (2020). Pengaruh Kecanggihan Teknologi Informasi, Partisipasi Manajemen, Pengetahuan Manajer Akuntansi terhadap Efektivitas Sistem Informasi Akuntansi (Studi Kasus pada Hotel Berbintang Tiga dan Empat di Kota Semarang). Jurnal Ilmiah Aset, 22(2), hal. 79-88. https:/ / doi.org/10.37470/1.22.2.164

Suadnyana, I Wayan Sui. (2020). Transmisi Lokal Tinggi, Disperindag Bali Gandeng Satpol PP dan Polri Sidak 3 Pasar di Mengwi Badung. https:/ / bali.tribunnews.com (diakses tanggal 15 September 2020).

Suartika, K. A., \& Widhiyani, N. L. S. (2017). Kemampuan Teknik Personal pada Efektivitas Penggunaan Sistem Informasi Akuntansi dengan Pendidikan dan Pelatihan sebagai Pemoderasi. E-Jurnal Akuntansi Universitas Udayana, 18(2), hal. 1485-1512.

Sugiyono, D. (2018). Metode Penelitian Kuatitatif, Kualitatif, dan RED. Bandung : CV Alfabeta.

Swara, L. G. I. P., \& Widhiyani, N. L. S. (2019). Pengaruh Komitmen Manajemen, Kemampuan Teknik Personal, dan Information Technology Sophistication pada Kinerja Sistem Informasi Akuntansi. E-Jurnal Akuntansi Universitas Udayana, 28(1), hal. 694-721. https:// doi.org/10.24843/ eja.2019.v28.i01.p27

Turnip, T. R. E. br., \& Suardikha, I. M. S. (2018). Pengaruh Kemampuan Teknik Personal, Pelatihan dan Pendidikan terhadap Efektivitas Penggunaan SIA pada Rumah Sakit. E-Jurnal Akuntansi Universitas Udayana, 22(2), hal. 14191444. https:// doi.org/10.24843/EJA.2018.v22.i02.p22

Unayah, E. (2020). Program Pendidikan dan Pelatihan terhadap Kinerja Sistem Informasi Akuntansi (Studi Kasus pada Kantor Kementerian Agama Kab. / Kota di Provinsi Banten). Jurnal Riset Akuntansi Tirtayasa, 5(1), hal. 57-72.

Widiantari, N. M. S., \& Mertha, M. (2018). Pendidikan dan Pelatihan Memoderasi Pengaruh Teknologi Informasi dan Kemampuan Pemakai pada Kinerja Sistem Informasi Akuntansi. E-Jurnal Akuntansi Universitas Udayana, 22(1), hal. 804-830. https:// doi.org/10.24843/EJA.2018.v22.i01.p30 